\title{
Research on the Construction Path Based on the Framework of Zhejiang Territorial and Spatial Planning System
}

\author{
Pengcheng Qiu ${ }^{1}$ \\ ${ }^{1}$ Zhejiang Wenling City Planning and Design Institute Wenling, Zhejiang 317500
}

\begin{abstract}
In order to effectively improve the construction level of Zhejiang Province's territorial and spatial system and its spatial governance capabilities, it is necessary to redeploy the province's territorial and spatial planning based on the actual development of Zhejiang Province. With the rapid advancement of the urban integration work in Zhejiang Province, the increasingly prominent problems such as the deterioration of the ecological environment, the chaotic order of land use, and the large differences in regional development have made land and space development and governance more difficult. In order to effectively improve this situation, this article Taking Zhejiang Province as an example, the author discussed the basic path of constructing the framework of Zhejiang's territorial and spatial planning system, hoping to play a certain role in promoting Zhejiang's territorial and spatial planning.
\end{abstract}

\section{Preface}

The land is the main place for a country to exercise its sovereignty. The realization of the development, protection and management of the land is a sign of the ability of a ruling party to govern. Wang B etc. [1] according to their own work experience, first of all national spatial planning work content has carried on the detailed comb, from the macro, meso and micro level is analyzed, the three space scales and preliminary constructed by national, provincial, city, county, township as the main body of the "five levels" national spatial planning study system, hope that through the application of the framework, It provides reference for other provinces and cities in China .Su SL and others[2].First, it analyzes the advantages and disadvantages of the current urban and rural planning system and land use planning system in China, and proposes a path to construct a land-building spatial planning system supported by national policies and regulations, technical standards, operating rules, and feedback mechanisms. It is proposed to make the specific goals, working methods and tasks of China's territorial and spatial planning work clearer. In the following, the author combines practical experience and relevant literature materials, starting from the positioning of the territorial and spatial planning system, and conducts an in-depth discussion on the construction path of the framework of the territorial and spatial planning system in Zhejiang.

\section{POSITIONING OF THE TERRITORIAL AND SPATIAL PLANNING SYSTEM}

\subsection{Connotation explanation}

Territorial and spatial planning refers to the implementation of a series of specific measures in the planning and deployment of territorial resources to effectively solve the problems of incomplete data, chaotic coordinate systems, and inconsistent control rules in the national land resource planning and management. At the same time, it should be in the national territory. Scientific and reasonable land and space governance and structural optimization based on space background conditions, to achieve a rational evaluation of the environmental carrying capacity of land and resources and the adaptive development of land and resources, divide control lines according to different uses of land and space, and then implement various types of space management The overall planning and coordination of methods will gradually form modern land and space governance tools that can reflect the strategic, comprehensive, coordinated, real-time, and policy nature of national development.

\subsection{Build requirements}

As far as the national planning system is concerned, good territorial and spatial planning can play a necessary role in guiding and restricting special plans. Therefore, the construction of the territorial and spatial planning system must conform to the strategic goals of national development to meet the guidance and constraints of other 
classified plans. Specifically, the following three requirements should be met: (1) To be able to coordinate, manage and control the global planning, and finally to integrate all the classified plans into the administrative field; (2) To be able to deal with "mountains, waters, forests, lakes", etc. Classified management of natural resources ecological space highlights its functions. (3) Realize the sharing and sublimation of the advantages in the existing spatial planning, and maximize the utilization of land resources; for the deficiencies in the planned planning, a systematic analysis shall be carried out to find out the reasons, and make timely corrections, if necessary Resolutely abandon the use, so as not to affect the smooth progress of other classification planning work.

\section{BASED ON THE CONSTRUCTION OF THE FRAMEWORK OF ZHEJIANG'S TERRITORIAL AND SPATIAL PLANNING SYSTEM}

The construction of the territorial and spatial planning system is based on an important opportunity in the era of smart planning. The following will introduce in detail the division of territorial and spatial planning levels, the supporting system for the construction of the planning framework, and the main planning paths:

\subsection{Space level}

Due to the different levels of the territorial and spatial planning system, the objects they target are also different, and the focus of their work is somewhat focused. Therefore, in the process of building the territorial and spatial planning system, it is necessary to "classify and establish territorial and spatial planning". Specifically, it is required that the spatial planning framework must contain detailed content such as research levels, content, data, methods, and software models (Table 1).

TABLE I. TABLE 1 EXAMPLES OF REPRESENTATIVE RESEARCH CONTENT AT DIFFERENT SPATIAL LEVELS

\begin{tabular}{|c|c|c|c|c|c|c|c|c|}
\hline Space level & $\begin{array}{l}\text { First class } \\
\text { classification }\end{array}$ & $\begin{array}{l}\text { Secondary } \\
\text { classification }\end{array}$ & $\begin{array}{l}\text { research } \\
\text { content }\end{array}$ & $\begin{array}{l}\text { Detailed } \\
\text { explanation }\end{array}$ & data & $\begin{array}{l}\text { Theoretical } \\
\text { method }\end{array}$ & model & software \\
\hline country & Spatial pattern & $\begin{array}{c}\text { Spatial } \\
\text { structure }\end{array}$ & $\begin{array}{c}\text { Regional } \\
\text { function } \\
\text { pattern }\end{array}$ & $\begin{array}{l}\text { Analyze the } \\
\text { role of } \\
\text { different } \\
\text { regional } \\
\text { spaces to } \\
\text { human } \\
\text { production life } \\
\text { within the } \\
\text { whole range }\end{array}$ & $\begin{array}{c}\text { Environmental } \\
\text { capacity } \\
\text { ecosystem } \\
\text { natural } \\
\text { disaster } \\
\text { population } \\
\text { density } \\
\text { economy level } \\
\text { land use } \\
\text { traffic } \\
\end{array}$ & $\begin{array}{c}\text { Type } \\
\text { distinguishing, } \\
\text { hydrological } \\
\text { analysis, stack } \\
\text { analysis, land } \\
\text { statistical } \\
\text { analysis, } \\
\text { integrated } \\
\text { zone }\end{array}$ & $\begin{array}{c}\text { Geological } \\
\text { function zone } \\
\text { division model }\end{array}$ & $\begin{array}{c}\text { SPSS, ArcGIS, } \\
\text { Matilab,Excel, } \\
\text { ect }\end{array}$ \\
\hline Provincial & Spatial pattern & $\begin{array}{c}\text { Spatial } \\
\text { organization }\end{array}$ & $\begin{array}{c}\text { Spatial } \\
\text { connection }\end{array}$ & $\begin{array}{l}\text { Study the } \\
\text { space } \\
\text { connection } \\
\text { between the } \\
\text { provincial } \\
\text { cities }\end{array}$ & $\begin{array}{l}\text { Provincial } \\
\text { economic } \\
\text { statistics, } \\
\text { urban people, } \\
\text { logistics, } \\
\text { traffic flow, } \\
\text { information } \\
\text { flow, data } \\
\end{array}$ & $\begin{array}{c}\text { Comprehensiv } \\
\text { e analysis of } \\
\text { gravitational } \\
\text { model }\end{array}$ & $\begin{array}{c}\text { Urban Contact } \\
\text { Evaluation } \\
\text { Analysis } \\
\text { Model }\end{array}$ & $\begin{array}{c}\text { ArcGIS,Uoinet } \\
\text {,Excel,Python, } \\
\text { ect }\end{array}$ \\
\hline $\begin{array}{l}\text { City - county - } \\
\text { township }\end{array}$ & Land function & Urban land & $\begin{array}{c}\text { Land effective } \\
\text { utilization }\end{array}$ & $\begin{array}{c}\text { Comprehensiv } \\
\text { e evaluation of } \\
\text { its effective } \\
\text { utilization by } \\
\text { urban spatial } \\
\text { structure, } \\
\text { spatial } \\
\text { distribution } \\
\text { and traffic } \\
\end{array}$ & $\begin{array}{l}\text { Land area, } \\
\text { land price, } \\
\text { industrial } \\
\text { output value, } \\
\text { employment } \\
\text { scale, traffic } \\
\text { flow }\end{array}$ & $\begin{array}{c}\text { Input output } \\
\text { analysis DEA } \\
\text { model }\end{array}$ & \begin{tabular}{c}
\multicolumn{1}{c}{ Land } \\
utilization \\
evaluation \\
model rate
\end{tabular} & $\begin{array}{c}\text { Matlab,DEAP, } \\
\text { Excel,SPSS,ec } \\
t\end{array}$ \\
\hline
\end{tabular}

\subsection{Support system}

(1) Comprehensive transportation system

In order to implement the transportation system layout requirements in the upper planning and related special plans as soon as possible, the Zhejiang Land and Resources Management Department has formulated a series of strategies to promote the comprehensive development of transportation. This strategic deployment provides clear functions, grades, and divisions to comprehensive transportation facilities at the county level and above, such as roads, railways, airports, ports, and urban rails, to meet the requirements of urban-rural integrated development and provide for the optimization of urban-rural transportation network. Strong reference

(2) Public service facility system
When working on the components of the public service facility system, we must first understand the overall spatial layout of the province's important public service facilities, as well as the requirements and supporting standards for the layout of public service facilities in each township, and require a reasonable layout to achieve urban and rural equalization.

(3) Green municipal infrastructure system

In order to meet the needs of green municipal development, we must first focus on the water supply guarantee demonstration work that people depend on, and put forward clear sanitation requirements for water sources, hydrological information, municipal water supply and drainage, etc.; secondly, the development goals of urban environmental protection and funeral facilities. The scale is planned to be green, 
environmentally friendly, and in line with the goal of effective use of land and resources.

(3) Security and resilience disaster prevention and mitigation system

In the construction of the security, resilience, disaster prevention and mitigation system, based on the actual situation, the type and extent of major natural disasters that may occur in the region are accurately assessed, and various disaster prevention infrastructure and emergency service facilities are added in combination with the local economic status. The long-term emergency response mechanism is to formulate comprehensive prevention and control measures under the premise of meeting the basic requirements of flood control, drainage, earthquake resistance, geological disasters, and marine disasters..

\subsection{Plan implementation guarantee}

Strengthen plan management

When planning land and space, it is necessary to closely follow the principle of "planning by space, plan by stock, and plan by occupation", and gradually improve the annual utilization plan and management requirements of various natural resources of land, sea, forest, and mining. To achieve sustainable development goals.

Implement boundary management

In the work of border management and control, the bottom line and red line of the national land plan must first be studied in depth to draw the boundaries, and then the borders shall be divided under the constraints of relevant national laws and regulations, and border management and control shall be carried out in strict accordance with relevant management and control requirements. In accordance with the principle of "management according to law, guaranteeing quantity, improving quality, optimizing layout, and clarifying conditions", zoning planning of land and space use is carried out. At the same time, special management and control regulations are formulated in accordance with the actual situation of local work, so that the space access and special purpose of different planning zones Become clearer and more standardized.

Optimize the land structure and layout of national land space Adjust the land use structure according to the national land and space planning standards, and through the in-depth study of the "Zhejiang Province Land and Space Planning Zoning and Land Classification Guidelines (Trial)", truly understand the "increased scale and reduction ratio of the first-level land category" indicated in the guide "Requirements, use this as a guide to compile a land-use structure adjustment table.

Put forward protection and utilization goals for agricultural land, strictly control the occupation of ecological and agricultural land for various constructions; insist on the priority of conservation and intensiveness for construction land, and encourage the conversion to the direction of use that is conducive to the improvement of ecological functions; make the entire land natural reserve land Unified planning for rivers, lakes, and wetlands; in terms of sea areas, strictly control the scale of mariculture and planting to ensure the preservation of the natural shoreline of the mainland and islands.

Periodic evaluation and timely revision

Strictly implement the "one-year inspection and five-year evaluation" system to strengthen state monitoring. During the monitoring process, if there is any violation of planning control, strict warnings will be given to relevant units and individuals, and their corresponding legal responsibilities will be investigated if necessary. According to local reality, targeted amendments to the types and conditions of land resources are made under the constraints of relevant national laws and regulations to ensure a certain degree of objectivity.

\section{STUdY ON THE IMPLEMENTATION OF THE PATH OF LAND AND SPACE PLANNING}

\subsection{Municipal Land and Space Master Plan}

The municipal-level land and space master plan shall implement the binding indicators and rigid control requirements issued by the national and provincial land and space master plans and related special plans; clarify the overall goals and patterns of land and space development and protection, and optimize the important ecological, agricultural, and urban areas within the city. , Marine development and protection space structure and layout; overall arrangement of major projects in the protection, development, utilization, and restoration of land and space within the city area; coordination of various contradictions in the development and protection of land and space across the city area and within the city area; delineation of the city-level central urban area and optimization Layout of the central city, strengthen the structural management and control of the blue-green space in the central city, the protection of historical and cultural relics; divide the municipal area into one or more county-level (district) planning units based on the actual situation; build a land and space plan that is coordinated by the city and county The map" implements the supervision information system, formulates plans and implements guarantee mechanisms and policy measures.

\subsection{County-level land and space master plan}

The county-level land and space master plan should further refine and implement the binding indicators and rigid control requirements issued by the higher-level land and space plan; clarify the overall goal of the county' s land and space development and protection; make overall plans and implement the red line of ecological protection, permanent basic farmland, and urban development boundaries. Three basic control lines" and important space control areas such as historical and cultural protection, "blue-green space", open space, important infrastructure, public service facilities, etc.; define the planned use zoning and put forward management and control requirements; delimit the county-level central urban area; Divide township-level territorial and spatial master planning areas and decompose and issue planning 
indicators; build a "one map" database for territorial and spatial planning, and implement safeguard measures for planning implementation.

\subsection{Township level land and space master plan}

The township-level territorial space master plan shall implement the binding indicators and control requirements issued by the higher-level planning on the ground; make overall plans and implement the boundaries and coordinates of the "three basic control lines" and other important spatial control lines; determine the use of the land, and Clarify control rules; implement various protection, development, utilization and restoration projects and projects; divide detailed planning preparation units, and propose detailed planning preparation guidelines, standards and requirements; complete territorial and spatial planning data storage.

\subsection{Detailed planning of land and space}

The detailed planning shall be based on the overall plan, and implement implementation arrangements for the specific land use, intensity and control requirements. In concentrated construction areas within the boundaries of urban development, the main preparation of detailed plans for urban units, strengthening urban design and style protection, improving spatial quality, highlighting the control of construction and development intensity, and detailing the layout of various infrastructure and public service facilities and land use structure; For rural areas outside the boundaries of urban development, village planning is mainly prepared with one or several administrative villages as units, making overall arrangements for various types of land in the village, and clarifying the use, intensity, and control requirements of the plots to promote the implementation of the rural revitalization strategy. Encourage all localities to explore and formulate detailed plans led by ecology, countryside or other specific functions to adapt to the particularity of the protection and utilization of different functional units in the management of activities.

\section{CONCLUDING REMARKS}

The construction of the territorial and spatial planning system can not only play a very positive role in promoting national economic development, but also fully reflect the integration and abolition of the current provincial territorial and spatial planning. Therefore, it is significance and far-reaching. The author of this article is based on the realities of the development of the land and space norms in Zhejiang Province, and through the analysis of many problems in the actual work, briefly explained the path of the construction of the land and space system based on the feelings of a big country. I hope that this research can effectively promote the work of the national land and space planning. Orderly development.

\section{REFERENCES}

1. BeiWang;XiaochunHuang;DaoshengSun ; YilongRong; TengyunHu . Thoughts on the construction of a quantitative research framework system for land and space planning[J]. Urban and Rural Planning, 2019-(12)-15.

2. ShiliangSu; ZaiyangLu; WeiWang; YangXiao ; ZhouluYu. Implementation evaluation of land and space planning: conceptual framework and index system construction[J].Geographic Information World, 2019-(08)-25.

3. Mei.Huang The construction path of the supervision system of land and space planning implementation based on the game theory of planning rights $[\mathrm{J}]$. Planner, 2019-(07)-31 